\title{
In vitro Studies on Efficacy of Some Plant Extracts and Biocontrol Agents against Lasiodiplodia theobromae and Lasiodiplodia pseudotheobromae
}

\author{
Rahee Bui, Bireswar Sinha*, Ph. Sobita Devi, Roseline Salam, \\ K. Dinesh and Tusi Chakma
}
Department of Plant Pathology, College of Agriculture, Central Agricultural University, Imphal-795004, India

*Corresponding author

\begin{abstract}
Key words
Mango, Postharvest, Plant extracts, Trichoderma spp

Article Info

Accepted: 06 June 2018 Available Online: 10 July 2018 (KU933474), T. asperellum (KU933475), T. asperellum KU933476) and T. hypocrea (KX0113223) were evaluated against the pathogens through production of non-volatile (Dennis and Webster, 1971a) and volatile Dennis and Webster, 1971b) compounds. The results revealed that among plant extracts, the highest inhibition for Lasiodiplodia theobromae was shown by garlic at $1.25,2.5$ and 5 per cent of 100 per cent and for Lasiodiplodia pseudotheobromae, the highest inhibition was showed by garlic at 5 per cent of 81.17 per cent. Effect of volatile compounds produced by Trichoderma spp against Lasiodiplodia theobromae showed maximum percentage inhibition with isolate $T$. asperellum (KU933476) of 95.24 per cent and T. hypocrea (KX0113223) least by 68.52 per cent. Effect of volatile compounds produced by Trichoderma spp against Lasiodiplodia pseudotheobromae showed maximum percentage inhibition with isolate $T$. ovalisporum (KU904456) of 12.39 per cent and no inhibition was observed by $T$. asperellum (KU933475), T. atroviride (KU933472), T. harzianum (KU933474), T. harzianum (KU933458), T.koningiopsis (KU904460), and T. hypocrea (KX0113223) against the pathogen. Effect on non-volatile compounds produced by Trichoderma spp. at two different concentrations viz., 7.5\% (v/v) and $15 \%(\mathrm{v} / \mathrm{v})$ against Lasiodiplodia theobromae showed 42.36 to 82.40 per cent at $7.5 \%$ v/v concentration and 53.70 to 100.00 per cent at $15 \% \mathrm{v} / \mathrm{v}$ concentration, In Lasiodiplodia pseudotheobromae, results showed 3.59 to 56.31 per cent at $7.5 \% \mathrm{v} / \mathrm{v}$ concentration and 44.47 to 100.00 per cent at $15 \% \mathrm{v} / \mathrm{v}$ concentration. Present study suggests that Garlic and Trichoderma spp. could be tried for the eco-friendly management of the diseases.
\end{abstract}

\section{A B S T R A C T}

Stem-end rot of mango caused by Lasiodiplodia theobromae and Lasiodiplodia pseudotheobromae is a major post-harvest problem in Manipur and reduces yield. An experiment on antifungal efficacy of three plant extracts viz., Garlic (Allium sativum), Neem (Azadirachta indica) and Ginger (Zingiber officinale) was done through poisoned food technique by taking three concentrations in in vitro conditions against the pathogens and eight Trichoderma isolates viz., T. ovalisporum (KU904456), T. koningiopsis (KU904460), T. harzianum (KU904458), T. atroviride (KU933472), T. harzianum 


\section{Introduction}

Mango (Mangifera indica L.) belongs to the family Anacardiaceae. It is one of the important fruit trees which is grown commercially both in tropical and subtropical region. Mango is a "national fruit" of India and known as "king of fruit". Records suggest that it has been in cultivation in the Indian subcontinent for well over 4000 years now (De Candolle, 1904). India is the leading producer and contributes $20 \%$ of the total fruit production with 18.43 million tonnes production and of productivity 7.3 million tonnes/ha. (Indian Horticultural Database, 2014). Though, Mango is an important constituent of the diet, however, mango is susceptible to a number of diseases at all stages of its development from the seedling to the fruits (Alemu, 2014). Also, Mango suffers from diseases worldwide caused by a variety of pathogens that affect all parts of the tree and therefore, reduce yield and quality of the fruit, (Saeed et al., 2017) Crop loss may be the outcome of fungal diseases while postharvest diseases may lead to the export losses (Prakash, 2004). The mango tree and fruit is the usually host of different pathogens specifically fungi which produces post-harvest fruit rot worldwide (Diedhiou et al., 2007). Diseased trees presence in orchards and inappropriate management practices may cause the destruction of whole mango orchard (Saeed et al., 2012). Lasiodiplodia theobromae responsible for stem end rot in which dark brown to black spots appear from the tip of mango and spread on whole fruit (Maqsood et al., 2014).

Because of the increasing concern over residual toxicity resulting from the wide spread use of synthetic fungicide and proliferation of resistance in the pathogen populations, attention has focused on natural substances (Alemu et al., 2014). Now scientists started to shift their focus on ecofriendly methods. These includes using of plant extracts due to their antifungal effects on the growth and development of post-harvest diseases of mango. Moreover, the residues of these fungicides remain in the harvested produce. Therefore, search for alternative disease control strategies are of immense interest. Biocontrol agents like Trichoderma isolates are promising in terms of their low cost, potential efficacy as well as no or negligible side effects. Plants and their derivatives have been extensively studied for the control of phytopathogenic fungi. Several studies have been carried out on inhibitory potential of many plant extracts and Trichoderma isolates against phytopathogenic fungi including species of Lasiodiplodia.

Hence, the present study was carried out to study the antifungal activity of some plant extracts and biocontrol agents against Lasiodiplodia theobromae and Lasiodiplodia pseudotheobromae under in vitro.

\section{Materials and Methods}

Three locally available botanicals namely Garlic (Allium sativum), Neem (Azadirachta indica) and Ginger (Zingiber officinale) were evaluated for their efficacy on the growth of the fungus at three concentrations in vitro. Different plant parts were used for the inhibitory effect against Lasiodiplodia theobromae and Lasiodiplodia pseudotheobromae namely Garlic clove, Neem leaves and Ginger rhizomes.

\section{Preparation of plant extraction}

The plant parts were collected, washed in running tap water, surface sterilized with $1 \%$ sodium hypochloride and then with sterile distilled water. These were air dried over a blotting paper. The air dried plant parts were crushed separately in sterilized mortar and pestle with sterile distilled water at ratio 1:1 
(w/v). These extracts were filtered through 2 fold muslin cloth and filtrate was centrifuged at $1500 \mathrm{rpm}$ for 15 minutes and the supernatants were collected. These extracts thus prepared were considered as $100 \%$ concentration.

Three concentrations were taken for each treatment. For the plant extracts, different concentrations taken were $1.25,2.5$ and $5 \%$. Required quantity of each treatment was added to the sterilized melted PDA medium in the conical flask under aseptic condition and was shaken for well mixing of the two. Each mixture was then poured into the sterilized petri plate under aseptic condition and allowed to solidify. Medium without any treatment and natural product served as control. After solidification, each plate was inoculated with $5 \mathrm{~mm}$ diameter mycelium disc cut from the periphery of actively grown culture on PDA. The plates were then incubated at $25 \pm 1{ }^{0} \mathrm{C}$ in inverted position. Observations on the fungal growth were taken till the control plates were fully covered by the test fungus. Each treatment was replicated 3 times with three plates in each replication. Per cent inhibition (PI) on growth was calculated by following the method described by Vincent (1927) as given below:

$\mathrm{PI}=\frac{(C-T)}{C} \times 100$

Where,

$\mathrm{C}=$ linear growth of the fungus in control

$\mathrm{T}=$ linear growth of the fungus in treatment

The effects of volatile antibiotics produced by antagonistic fungi, Trichoderma were studied by following methods of Dennis and Webster (1971b). The radial mycelial growth of test pathogen and antagonist were measured periodically and the per cent inhibition of mycelial growth of test pathogen by antagonists was calculated as per formulae adopted by Garcia (1991) as:

Percent Inhibition of Radial Growth (\% IRG)

$=100[(\mathrm{R}-\mathrm{R}) / \mathrm{R}]$, where,

$\mathrm{R}_{1}$ - the farthest radial distance grown by the pathogen in the direction of the antagonist.

$\mathrm{R}_{2}$ - the distance grown on a line between inoculation positions of the pathogen and antagonist

The ability of Trichoderma isolates to produce the non-volatile substances was studied following methods described by Dennis and Webster (1971a). The radial mycelial growth of test pathogen was measured and per cent inhibition of mycelial growth of pathogen was calculated according to Garcia (1991) as mentioned earlier

\section{Results and Discussion}

In vitro efficacy of plant extracts on the growth of Lasiodiplodia theobromae and Lasiodiplodia pseudotheobromae:

Three botanicals were used at concentrations of $1.25 \%, 2.5 \%$, and $5 \%$ each against $L$. theobromae and the per cent inhibition was recorded (Table 1, Plate 1, 2, 3). Cent percent inhibition had shown by garlic at $1.25,2.5$ and $5 \%$ and ginger at 2.5 and $5 \%$. Least inhibition was observed at ginger $1.25 \%$ with $28.23 \%$, followed by neem at $1.25 \%, 2.5 \%$ and $5 \%$ with $86.40 \%, 91.95 \%$ and $93.74 \%$ respectively.

Three botanicals were used at concentrations of $1.25 \%, 2.5 \%$ and $5 \%$ each against $L$. pseudotheobromae and per cent inhibition was recorded (Table 2, Plate 4, 5, 6). The highest per cent inhibition was showed in garlic at 5 $\%$ with $81.17 \%$ followed by garlic at $2.5 \%$ 
with $79.00 \%$. There was no inhibition of the pathogen by neem and ginger at all the three concentrations (1.25, 2.5 and 5) and garlic at $1.25 \%$.

The effect of volatile compounds produced by Trichoderma spp against Lasiodiplodia theobromae was examined and results are presented in Table 3 and Plate 7. Among the eight isolates of Trichoderma spp. tested, maximum percentage inhibition was recorded with isolate $T$. asperellum (KU933476) with 95.24 per cent inhibition followed by $T$. atroviride (KU933472) with 89.26 per cent inhibition. T. hypocrea (KX0113223) had shown least inhibition with 68.52 per cent. $T$. asperellum (KU933475), T. koningiopsis (KU904460), T. harzianum (KU904458), T. ovalisporum (KU904456) and T. harzianum
(KU933474) had shown 79.42 per cent, 76.36 percent, 87.34 per cent, 86.36 per cent and 74.47 per cent inhibition respectively.

The effect of volatile compounds produced by Trichoderma spp against Lasiodiplodia pseudotheobromae was examined and results are presented in Table 4 and plate 8 . Among the eight isolates of Trichoderma spp. tested, maximum percentage inhibition was recorded with isolate $T$. ovalisporum (KU904456) 12.39 per cent inhibition followed by $T$. asperellum (KU933476) 4.44 per cent inhibition. T. asperellum (KU933475), T. atroviride (KU933472), Trichoderma harzianum (KU933474), T. harzianum (KU933458), T. koningiopsis (KU904460) and T. hypocrea (KX0113223) had showed no inhibition against the pathogen.

Table.1 Effect of plant extracts on the growth of Lasiodiplodia theobromae

\begin{tabular}{|c|c|c|c|}
\hline \multirow[t]{2}{*}{ Treatment } & Plant part & Concentration & \multirow[t]{2}{*}{ Inhibition over control $(\%)$} \\
\hline & used & $(\%)$ & \\
\hline \multirow[b]{2}{*}{ Neem } & \multirow{2}{*}{ Leaf } & 1.25 & $86.40 *$ \\
\hline & & 2.5 & 91.95 \\
\hline & & 5 & 93.74 \\
\hline \multirow[t]{3}{*}{ Ginger } & \multirow{2}{*}{ Rhizome } & 1.25 & 28.23 \\
\hline & & 2.5 & 100.00 \\
\hline & & 5 & 100.00 \\
\hline \multirow[t]{3}{*}{ Garlic } & \multirow[t]{2}{*}{ Bulb } & 1.25 & 100.00 \\
\hline & & 2.5 & 100.00 \\
\hline & & 5 & 100.00 \\
\hline \multicolumn{4}{|l|}{ Control } \\
\hline \multirow[t]{3}{*}{$\mathrm{SE}(\mathrm{d})$} & & & 0.62 \\
\hline & & & \multirow[t]{2}{*}{1.31} \\
\hline & & & \\
\hline
\end{tabular}

*Mean of three replications 
Table.2 Effect of plant extracts on the growth of Lasiodiplodia pseudotheobromae

\begin{tabular}{|c|c|c|c|}
\hline Treatment & $\begin{array}{c}\text { Plant part } \\
\text { used }\end{array}$ & $\begin{array}{c}\text { Concentration } \\
(\%)\end{array}$ & \begin{tabular}{c} 
Inhibition over control (\%) \\
\hline
\end{tabular} Neem \\
\hline & Leaf & 1.25 & 0 \\
\hline & & 2.5 & 0 \\
\hline Ginger & Rhizome & 1.25 & 0 \\
\hline & & 2.5 & 0 \\
\hline Garlic & Bulb & 5 & 0 \\
\hline & & 1.25 & 0 \\
\hline & & 2.5 & 79.00 \\
\hline Control & & 5 & 81.17 \\
\hline SE(d) & & & 0.49 \\
\hline & & & 1.03 \\
\hline
\end{tabular}

*Mean of three replications

Table.3 Effect of volatile and non-volatile compounds of Trichoderma spp. on growth of Lasiodiplodia theobromae

\begin{tabular}{|c|c|c|c|c|}
\hline \multirow{2}{*}{$\begin{array}{l}\text { SL. } \\
\text { No. }\end{array}$} & \multirow[t]{2}{*}{ Trichoderma spp. } & \multicolumn{3}{|c|}{ Inhibition over control } \\
\hline & & \multirow{2}{*}{$\begin{array}{c}\text { Volatile } \\
\text { compounds }(\%)\end{array}$} & \multicolumn{2}{|c|}{ Non volatile compounds } \\
\hline & & & $(7.5 \%)$ & $(15 \%)$ \\
\hline 1 & T. asperellum (KU933475) & $79.42 *$ & $51.32 *$ & $75.34^{*}$ \\
\hline 2 & T. koningiopsis (KU904460) & 76.36 & 71.53 & 81.49 \\
\hline 3 & T. hypocrea(KX0113223) & 68.52 & 82.40 & 100.00 \\
\hline 4 & T. harzianum(KU904458) & 87.34 & 42.36 & 53.70 \\
\hline 5 & T. ovalisporum(KU904456) & 86.36 & 70.32 & 79.67 \\
\hline 6 & T. atroviride (KU933472) & 89.26 & 79.42 & 96.35 \\
\hline 7 & T. asperellum(KU933476) & 95.24 & 75.20 & 89.27 \\
\hline \multirow[t]{3}{*}{8} & T. harzianum (KU933474) & 74.47 & 46.55 & 74.31 \\
\hline & $\mathrm{SE}(\mathrm{d})$ & 0.81 & 0.82 & 0.74 \\
\hline & & 1.68 & 1.70 & 1.55 \\
\hline
\end{tabular}

*Mean of three replications 
Plate 1

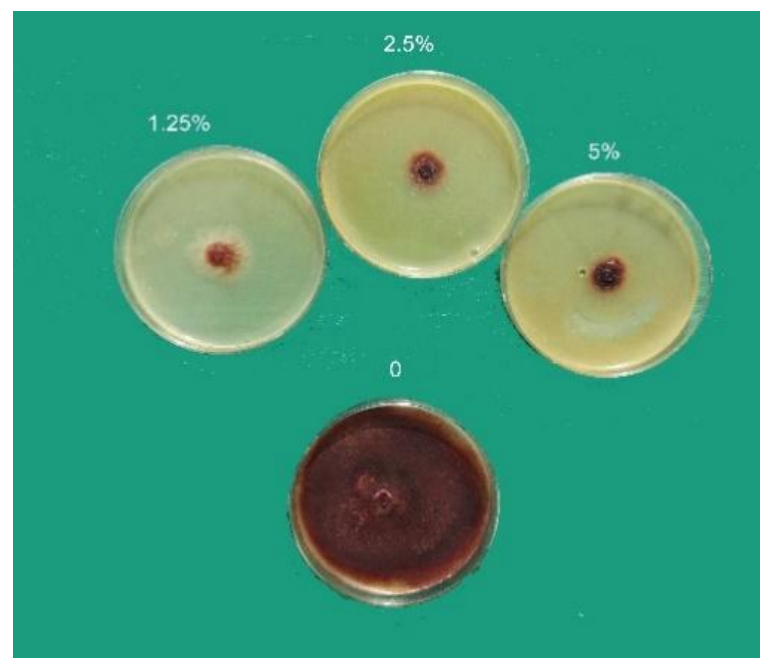

Plate 3

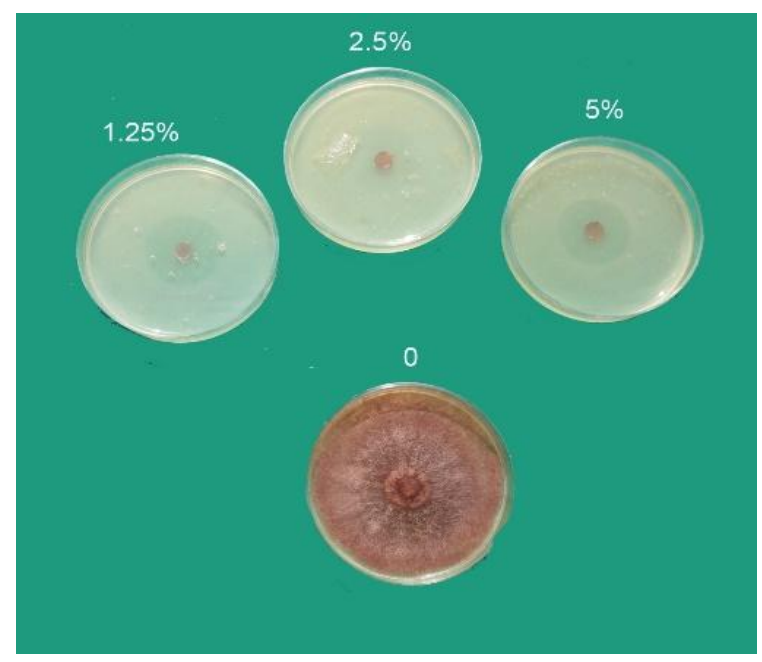

Plate 5

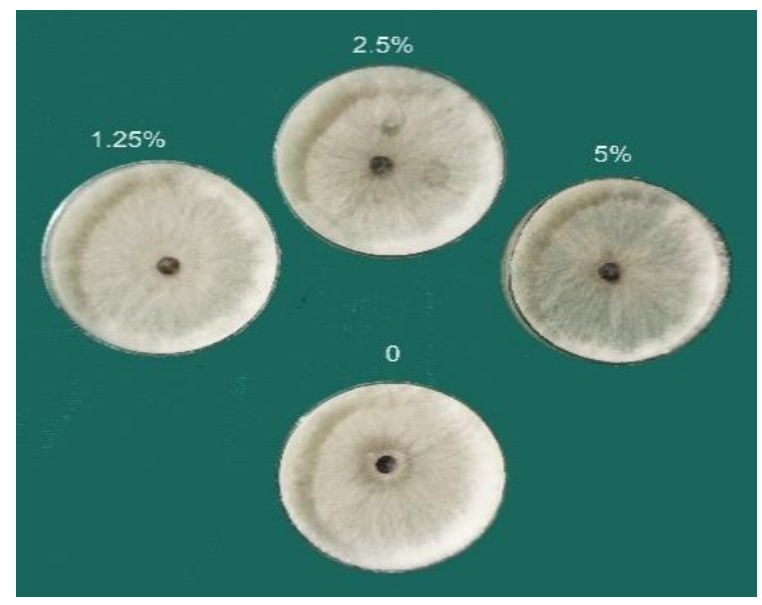

Plate 2

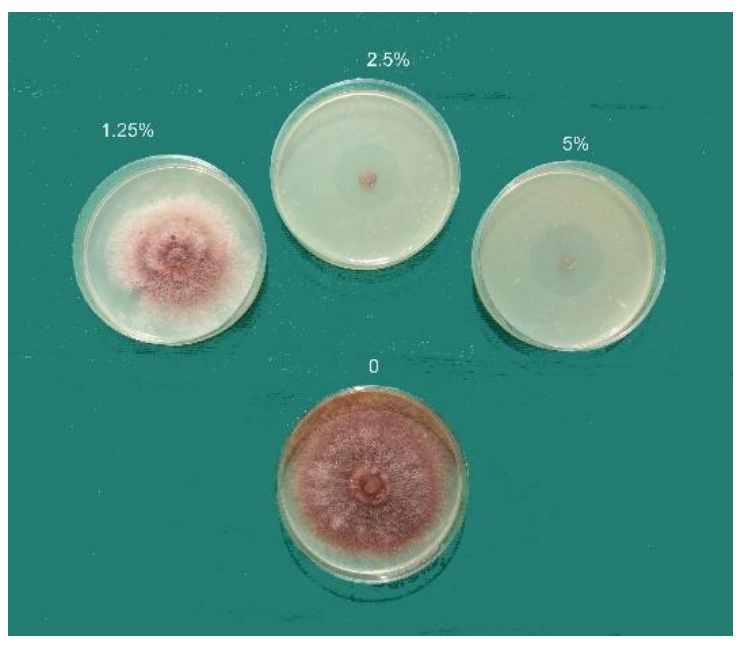

Plate 4

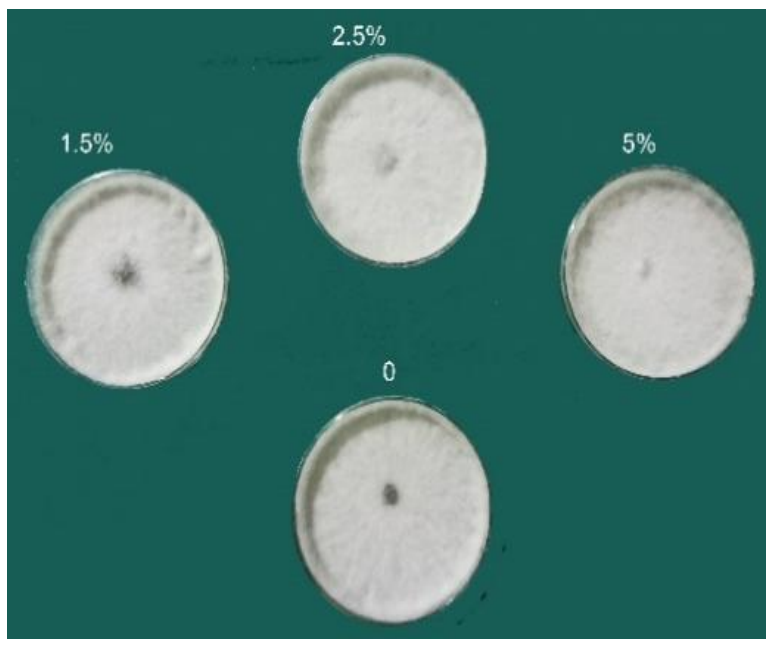

Plate 6

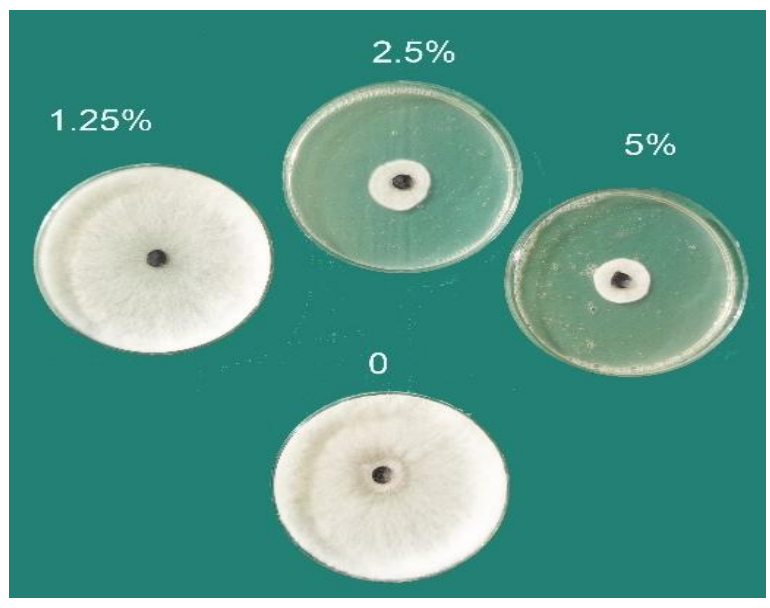


Plate 7

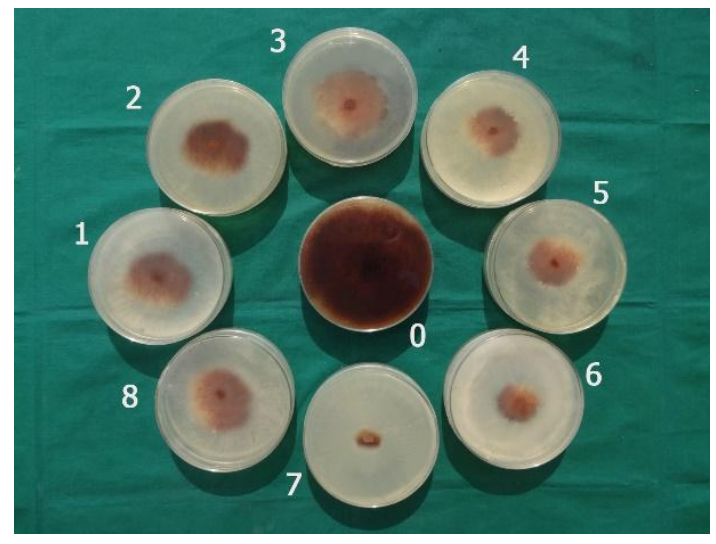

Plate 9(a)

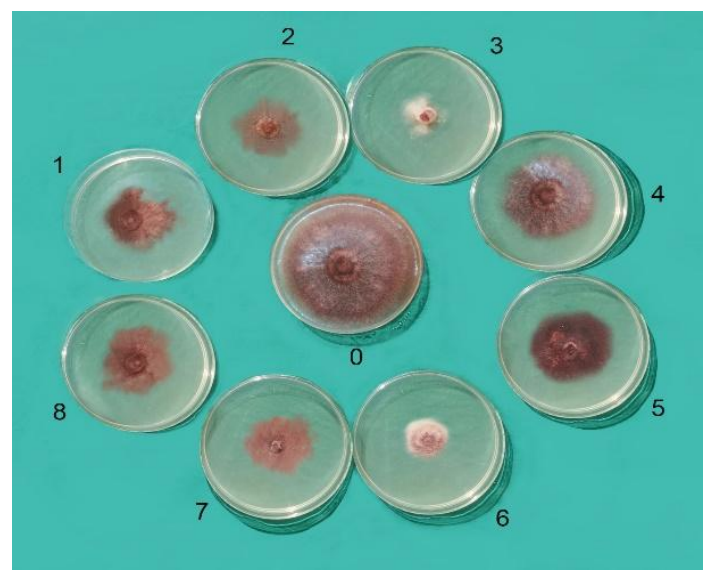

Plate 10 (a)

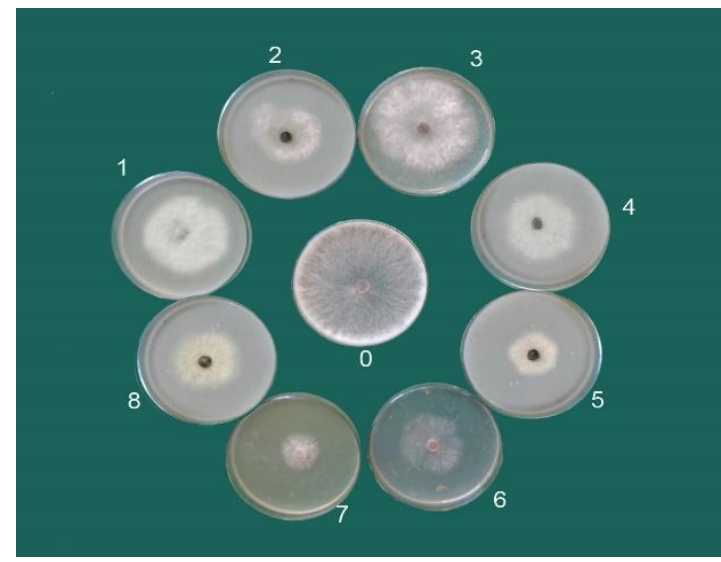

Plate 8

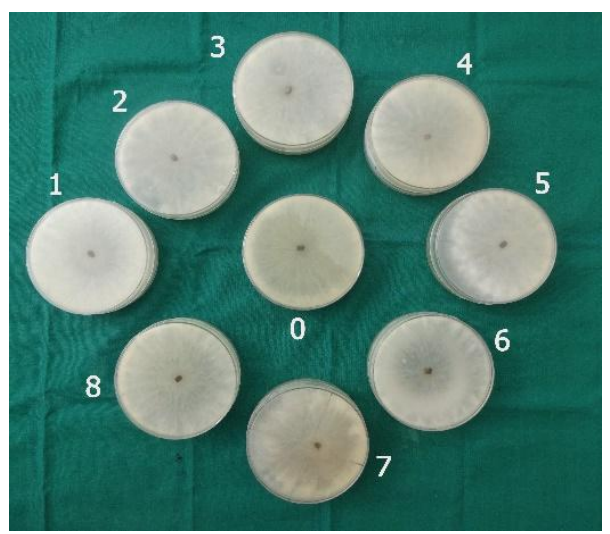

Plate 10(b)

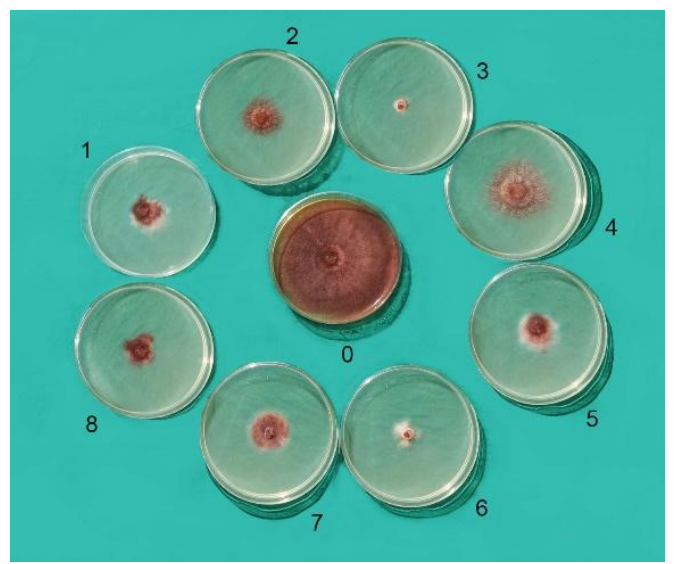

Plate 10 (b)

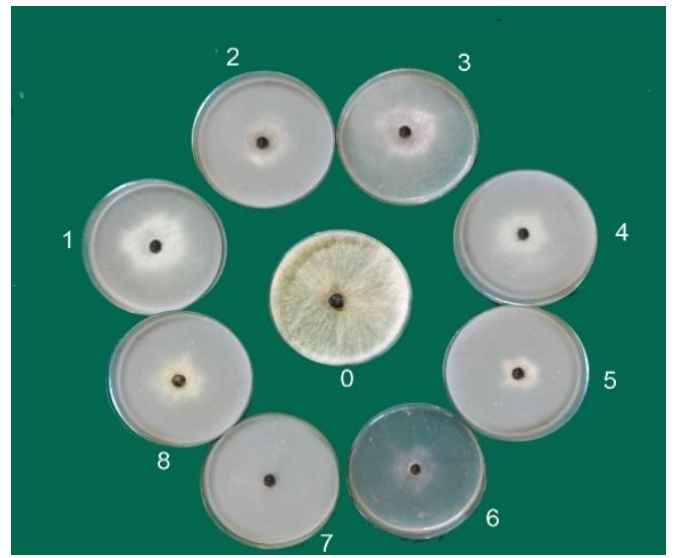

1. T. asperellum(KU933475)

3. $T$. hypocrea $(\mathrm{KX0113223})$

5. T. ovalisporum(KU904456)

7. T. asperellum(KU933476)

0. CONTROL
2. T.koningiopsis(KU904460)

4. T. harzianum(KU904458)

6. $T$. atroviride (KU933472)

8. T. harzianum(KU933474) 
Table.4 Effect of volatile and non-volatile compounds of Trichoderma spp.on growth of Lasiodiplodia pseudotheobromae

\begin{tabular}{|c|c|c|c|c|c|}
\hline \multirow{4}{*}{$\begin{array}{l}\text { SL. } \\
\text { No. }\end{array}$} & \multirow[t]{2}{*}{ Trichoderma spp. } & & \multicolumn{2}{|c|}{ Inhibition over control } & \\
\hline & & \multicolumn{2}{|c|}{ Volatile compounds } & \multirow{2}{*}{\multicolumn{2}{|c|}{$\begin{array}{l}\text { Non volatile } \\
\text { compounds }\end{array}$}} \\
\hline & & & & & \\
\hline & & & (\%) & $(7.5 \%)$ & $(15 \%)$ \\
\hline 1 & T. asperellum (KU933475) & $\begin{array}{r}0 *(0.7 \\
0)\end{array}$ & & $13.64 *$ & $44.47^{*}$ \\
\hline 2 & T. koningiopsis (KU904460) & \multicolumn{2}{|l|}{$0(0.70)$} & 40.32 & 57.56 \\
\hline 3 & T. hypocrea $(\mathrm{KX} 0113223)$ & \multicolumn{2}{|l|}{$0(0.70)$} & 3.59 & 50.48 \\
\hline 4 & T. harzianum (KU904458) & \multicolumn{2}{|l|}{$0(0.70)$} & 21.37 & 53.52 \\
\hline 5 & T. ovalisporum(KU904456) & \multicolumn{2}{|c|}{$12.39(3.58)$} & 49.35 & 61.20 \\
\hline 6 & T. atroviride(KU933472) & \multicolumn{2}{|c|}{$0(0.70)$} & 42.34 & 63.46 \\
\hline 7 & T. asperellum(KU933476) & \multicolumn{2}{|c|}{$4.44(2.21)$} & 56.31 & 100 \\
\hline \multirow[t]{3}{*}{8} & T. harzianum (KU933474) & \multicolumn{2}{|l|}{$0(0.70)$} & 46.53 & 63.47 \\
\hline & $\mathrm{SE}(\mathrm{d})$ & \multicolumn{2}{|l|}{0.06} & 0.78 & 0.81 \\
\hline & & \multicolumn{2}{|l|}{0.14} & 1.63 & 1.69 \\
\hline
\end{tabular}

*Mean of three replications

Values in parentheses are square root transformed values

The effect of non-volatile compounds produced by Trichoderma spp. at two different concentrations viz., $7.5 \%(\mathrm{v} / \mathrm{v})$ and $15 \%$ (v/v) were studied against Lasiodiplodia theobromae and results are presented in Table 3 and Plate 9(a) and 9(b). Results showed that per cent inhibition of Lasiodiplodia theobromae by eight isolates of Trichoderma spp. were ranged from 42.36 per cent to 82.40 per cent at $7.5 \% \mathrm{v} / \mathrm{v}$ concentration and from 53.70 per cent to 100.00 per cent at $15 \% \mathrm{v} / \mathrm{v}$ concentration. The highest per cent percent inhibition at 7.5 and $15 \% \mathrm{v} / \mathrm{v}$ concentration was recorded with the isolate $T$. hypocrea (KX0113223) where the inhibition percentage was 82.40 and 100.00 per cent. The inhibition percentage of other isolates at $7.5 \% \mathrm{v} / \mathrm{v}$ were T. asperellum (KU933475), 51.32 per cent, $T$. koningiopsis (KU904460), 71.53 per cent, $T$. ovalisporum (KU904456) 70.32 per cent, $T$. atroviride (KU933472) 79.42 per cent, $T$. asperellum (KU933476) 75.20 per cent and $T$. harzianum (KU933474) 46.55 per cent respectively. The inhibition percentage of other isolates at $15 \% \mathrm{v} / \mathrm{v}$ were T. asperellum (KU933475), 75.34 per cent, T. koningiopsis (KU904460) 81.49 per cent, T. ovalisporum (KU904456) 79.67 per cent, T. atroviride (KU933472) 96.35 per cent, T. asperellum (KU933476) 89.27 per cent and T. harzianum (KU933474) 74.31 per cent respectively.

The effect of non-volatile compounds produced by Trichoderma spp. at two different concentrations viz., $7.5 \%(\mathrm{v} / \mathrm{v})$ and $15 \%$ (v/v) were studied against Lasiodiplodia pseudotheobromae and results are presented in Table 4 and Plate 10(a) and 10(b). Results showed that per cent inhibition of Lasiodiplodia pseudotheobromae by eight isolates of Trichoderma spp. were ranged from 3.59 per cent to 56.31 per cent at $7.5 \%$ $\mathrm{v} / \mathrm{v}$ concentration and from 44.47 per cent to 100 per cent at $15 \% \mathrm{v} / \mathrm{v}$ concentration. The 
highest per cent inhibition at $7.5 \% \mathrm{v} / \mathrm{v}$ concentration and $15 \% \mathrm{v} / \mathrm{v}$ concentration was recorded with the isolate $T$. asperellum (KU933476) with 56.31 per cent and 100 per cent. Least inhibition at $7.5 \mathrm{v} / \mathrm{v}$ concentration was shown by T. hypocrea (KX0113223) 3.59 per cent and at $15 \% \mathrm{v} / \mathrm{v}$ concentration was shown by $T$. asperellum (KU933475) with 44.47 per cent. The inhibition percentage of other isolates at $7.5 \% \mathrm{v} / \mathrm{v}$ were $T$. asperellum (KU933475) 13.64 per cent, T. koningiopsis (KU904460) 40.32 per cent, T. harzianum (KU10.024458) 21.37, T. ovalisporum (KU904456) 49.35 per cent, T. atroviride (KU933472) 42.34 per cent and T. harzianum (KU933474) 46.53 per cent. The inhibition percentage of other isolates at $15 \% \mathrm{v} / \mathrm{v}$ were T. koningiopsis (KU904460), 57.56 per cent, T. hypocrea (KX0113223) 50.48 per cent, $T$. harzianum (KU904458), 53.52 per cent, $T$. ovalisporum (KU904456) 61.20 per cent, $T$. atroviride (KU933472) 63.46 per cent and $T$. harzianum (KU933474) 63.47 per cent respectively.

The inhibitory effect of Trichoderma spp. may be due to production of number of antibiotics such as Trichodermin, Trichodermol, Harzianum A, Harzianolide (Dennis and Webster, 1971; Kucuk and Kivanc, 2004) as well as some cell wall degrading enzymes such as chitinases, glucanases that break down polysaccharides, chitins and beta glucanase destroying cell wall (Elad, 2000). Trichoderma spp. are antagonistic to a range of fungi that

produce volatile and non-volatile antibiotics (Dennis and Webster, 1971a,b; Upadhyay and Mukhopadhyaya, 1983; Mukhopadhyay and Kaur, 1990; Pan and Bhagat, 2008). The present findings revealed that there was significant suppression of pathogens by the test antagonists, and this may be due to production of different types of volatile and non-volatile substances and its amount which was highly selective in their action. It also showed different degrees of inhibition on growth of Lasiodiplodia theobromae and Lasiodiplodia

\section{References}

Alemu, K., Ayalew, A. and Woldetsadic, K. (2014). Effect of aqueous extracts of some medicinal plants in controlling anthracnose disease and improving postharvest quality of mango fruit. Persian Gulf Crop Prot., 3(3): 84-92.

Diedhiou, P.M., Mbaye, N., Drame A. and Samb, P.I. (2007). Alteration of postharvest diseases of mango Mangifera indica through production practices and climatic factors. Afr. J. Biotechnol., 6(9): 1087-1094

De Candolle (1904) Origin of cultivated plants, Kegan Paul London.

Dennis, C. and Webster, J. (1971a). Antagonists properties of species groups of Trichoderma 1. Production of non-volatile antibiotics. T. Brit. Mycol. Soc., 57: 25-39.

Dennis, C. and Webster, J. (1971b). Antagonistic properties of species groups of Trichoderma 11.Production of volatile antibiotics. T. Brit. Mycol. Soc., 57: 41-48.

Elad, Y. (2000). Biological control of foliar pathogens by means of Trichoderma harzianum and potential modes of action. Crop Prot.,19: 709-714.

Indian Horticultural Database, (2014). National Horticulture Board. Ministry of Agriculture Government of India 85, Institutional Area, Sector-18, Gurgaon-122015, INDIA.

Kucuk, C. and Kivanc, M. (2004). In vitro antifungal activity of strains of Trichoderma harzianum. Turk. J. Biol., 28: 111-115.

Maqsood, A., Rehman, A., Ahmad, I., Nafees, M., Ashraf, I., Qureshi, R., Jamil, M., 
Rafay, M. and Hussain, T. (2014). Physiological attributes of fungi associated with stem end rot of mango (Mangifera indicaL.) cultivars in postharvest fruit losses. Pakistan J. Bot.,46: 1915-1920.

Mukhopadhyay, A.N. and Kaur, N.P. (1990). Biological control of chickpea wilt complex by $T$. harzianum. Abstract Proceedings of Third International Conference on Plant Protection in the Tropics, Malaysia, pp. 203.

Pan, S. and Bhagat, S. (2008). Characterization of Trichoderma species from West Bengal. J. Biol. Control, 22: 43-49

Prakash, O.M. (2004). Diseases and disorders of mango and their management. Diseases of fruits and vegetables,
Kakori, Lucknow, pp. 511-619.

Saeed, S., Masood, A. and Khan, S.M. (2012). Diseased plants as a source of dissemination of mango sudden death disease in healthy mango plants. Pakistan J. Phytopathol24: 2125.

Saeed, E.E., Sham, A., Abuzarqa, A., Shurafa, A.A., Naqbi, T.S.A., Iratni, R., Tarabily, K.E. and Abuqamar, S.F. (2017). Detection and management of mango dieback disease in the United Arabr Emirates. Intl. J. Mol. Sci., 18(2086): 1-18.

Upadhyay, J.P. and Mukhopadhyay, A.N. (1983). Effect of non-volatile and volatile antibiotics of Trichoderma harzianumon growth of Sclerotium rolfsii. J. Mycol. Pl. Pathol., 13: 232233.

\section{How to cite this article:}

Rahee Bui, Bireswar Sinha, Ph. Sobita Devi, Roseline Salam, K. Dinesh and Tusi Chakma. 2018. In vitro Studies on Efficacy of Some Plant Extracts and Biocontrol Agents against Lasiodiplodia theobromae and Lasiodiplodia pseudotheobromae. Int.J.Curr.Microbiol.App.Sci. 7(07): 448-457. doi: https://doi.org/10.20546/ijcmas.2018.707.054 